\title{
The Counterfeit Petrol Business in Benin and Associated Health Consequences Among Stakeholders
}

\author{
Gbankoto Mamatou, ", Gbaguidi Ahotondji Bertin ${ }^{1}$, Dotché Ogoudanan Ignace², Biaou Olivier, \\ Youssao Abdou Karim Alassane ${ }^{4}$, Akpovi Dêwanou Casimir ${ }^{1}$, Youssao Abdou Karim Issaka ${ }^{1}$ \\ ${ }^{1}$ Department of Medical Imaging Engineering and Radiobiology, University of Abomey-Calavi, Polytechnic School of Abomey-Calavi, \\ Cotonou, Bénin \\ ${ }^{2}$ Department of Animal Production and Health, University of Abomey-Calavi, Polytechnic School of Abomey-Calavi, Cotonou, Benin \\ ${ }^{3}$ Medical Imaging Unit, National Hospital and University center H. K. Maga, Cotonou, Benin \\ ${ }^{4}$ Department of Chemical Engineering - Processes, University of Abomey-Calavi, Polytechnic School of Abomey-Calavi, Cotonou, Benin
}

\section{Email address:}

mgbankoto@yahoo.fr (G. Mamatou), bgbaguidi2001@yahoo.fr (G. A. Bertin), dotcheign@gmail.com (D. O. Ignace),

biaouolivier@yahoo.fr (B. Olivier), youssaoalassane@gmail.com (Y. A. K. Alassane), Casimir.akpovi@gmail.com (A. D. Casimir),

iyoussao@yahoo.fr (Y. A. K. Issaka)

${ }^{*}$ Corresponding author

\section{To cite this article:}

Gbankoto Mamatou, Gbaguidi Ahotondji Bertin, Dotché Ogoudanan Ignace, Biaou Olivier, Youssao Abdou Karim Alassane, Akpovi Dêwanou Casimir, Youssao Abdou Karim Issaka. The Counterfeit Petrol Business in Benin and Associated Health Consequences Among Stakeholders. Central African Journal of Public Health. Vol. 6, No. 5, 2020, pp. 268-279. doi: 10.11648/j.cajph.20200605.15

Received: September 4, 2020; Accepted: September 17, 2020; Published: September 25, 2020

\begin{abstract}
In Benin counterfeit fuel is sold across the country, but the health consequences associated with this activity are not documented. The present study was conducted to describe the specificities of this business in a representative municipality of Southern Benin and to identify its health-related consequences as perceived by the vendors. Data was collected using a questionnaire survey in 160 vendors of counterfeit petrol in the municipality of Abomey-Calavi. The data were analyzed with SAS software and the proportions were compared two by two with the two-tailed $\mathrm{Z}$ test. The findings reveal that the trade of counterfeit petrol involves as many men $(53 \%)$ as women $(47 \%)$. The vendors have an average of 10.14 years of experience in the business. The conditions for practicing the profession are not optimal. Vendors store their fuel at the point of sale and they work more than 8 hours a day. Most of the respondents sold petrol at less than 400 F CFA (97.47\%). At this price, most of them (51.27\%) made a daily profit between 1000 and 5000 F CFA per day. Despite this daily profit, most of the respondents (73.20\%) wish to change their profession because of the perceived health hazards that can be caused by prolonged exposure to petrol. Most vendors said to experience fatigue $(82.76 \%)$, headache $(66.21 \%)$, dizziness $(60.69 \%)$ and skin irritations $(51.03 \%)$. Moreover, respiratory symptoms were reported by the respondents including mainly sneezing (69.92\%), stuffed nose (68.42\%), loss of smell $(55.64 \%)$, episodes of rhinorrhea $(53.38 \%)$ and throat irritations $(51.88 \%)$. The proportions of people reporting sneezing and stuffy nose were significantly higher $(p<0.05)$ than in the other categories. Despite these health risks, very few of them seek medical care when ill. A spatial distribution of vendors based on symptoms generated three main categories. The 1st group is composed of vendors from Glo-Djibé, Hèvié and Kpanroun. Those of group 2 are located in Akassato and Zinvié; while vendors from Godomey, Calavi, Togba and Ouédo made the last group. Frequently reported symptoms were dizziness, irritation of the eyes and loss of smell in the 1st group; episodes of rhinorrhea and irritation of the throat in group 2. Most symptoms reported in group 3 were headache, fatigue, lower back pain, stuffy nose and dental problems. Although the counterfeit petrol business generates interesting profits to traders, the associated hazards are enormous, hence the need to improve the technical and safety conditions of this sector.
\end{abstract}

Keywords: Counterfeit Fuel, Health Impact, Respiratory Symptoms, Benin 


\section{Introduction}

The socio-economic situation in Benin like in many other sub-Saharan African countries is characterized by a predominance of the informal economy [1]. The growth of the informal sector is due to the lack of alternatives, which increases the unemployment rates with the growth of various informal jobs that do not comply with any standards, rules and laws $[2,3]$. As a result, populations often develop "street economic activities" to meet their basic needs. Among these activities comes in a prime position, the illicit trade of counterfeit petrol in Benin. This large-scale illicit trafficking of petroleum products began in the 1980s and benefited from the proximity of Nigeria, the largest oil producer in Africa [4]. This activity helps families to meet household needs [2]. However, it constitutes a serious health, safety and environmental hazard for the traders in particular and the population in general [5]. Healthwise, a number of pathological problems are encountered, ranging from general manifestations to specific conditions such as respiratory distresses, gastrointestinal problems, central nervous system disorders, skin lesions and itching [6-8]. These health consequences can lead to the reduction of life expectancy, especially among younger vendors because the effects of continuous exposure to petroleum are more harmful during growth [9]. From a safety point of view, petrol is an inflammable product which often causes fires resulting in the death of vendors and those around them and other health problems following inhalation of the gas $[3,10$, 11]. Exposure to petrol is toxic and causes side effects such as inability to concentrate, memory loss, anxiety, depression and post-traumatic stress disorder [12, 13]. From an environmental standpoint, petroleum activities release generalized chemical contamination in various environmental compartments (air, soil, water and the food chain) $[11,14]$. In addition, environmental problems, in particular air pollution, constitute a high risk to public health $[9,14]$. To mitigate these safety and health problems, appropriate conditions for safety in handling petroleum products have been established and require the creation of petrol stations meeting certain safety requirements $[15,16]$. In order to preserve the health of the population in Benin, the government had unsuccessfully tried to enforce vendors to comply with the standards for the sale of petrol because in Benin, counterfeit petrol (locally knows as kpayo) is sold openly by the road side in bottles without any protection [3, 4, 11]. Multiple State-organized sensitizations and repressions failed because this activity has become the basis of the household economy of many vendors [4] but above all because they ignore the dangers of selling petrol under inappropriate conditions. There is therefore a need to educate them on the drawbacks associated with their handling methods and make them understand that an improvement in the conditions of sale of petrol will improve their health and reduce fires. Currently, the country does not have sufficient scientific information that can better guide the sensitization campaigns because the activity is not well characterized, and the health problems encountered by vendors are not documented. The purpose of this study is to depict the commercialization value chain of counterfeit petrol in Benin and provide an inventory of health symptoms commonly experienced by the stakeholders with a gender-balanced approach. The results of this study may help to improve the management of this sector.

\section{Material and Methods}

\subsection{Study Area}

The present study was conducted in the commune of Abomey-Calavi (Figure 1), located in the southern part of the Republic of Benin and in the Atlantic Department. This municipality is bounded to the north by the municipality of Zè, to the south by the Atlantic Ocean, to the east by the municipalities of Sô-Ava and Cotonou, and to the west by the municipalities of Tori-Bossito and Ouidah. It is the largest municipality in the Department of Atlantic, of which it occupies more than $20 \%$. It extends over an area of $539 \mathrm{~km}^{2}$ representing $0.48 \%$ of the national area of Benin. The hydrographic network is essentially made of two water bodies, Lake Nokoué and the coastal lagoon. The population density varies considerably within this department and is 1218 inhabitants per $\mathrm{km}^{2}$ in the municipality of AbomeyCalavi. The sex ratio of this department was 96.5 men for 100 women in 2013 [17]. The municipality of AbomeyCalavi has seventy (70) city districts and villages spread over nine (9) major districts that are: Abomey-Calavi Center, Godomey, Akassato, Zinvié, Ouèdo, Togba, Hêvié, Kpanroun and Golo-Djigbé. The main economic activities of the municipality are agriculture, fisheries, animal husbandry and trade.

\subsection{Methodology}

A cross-sectional study design was employed where a semi-structured questionnaire was developed for descriptive interviews with 160 vendors of counterfeit petrol "kpayo". The municipality of Abomey-Calavi was chosen because of its urban, peri-urban and rural areas and its representative population of the southern part of the country. Data were collected during exploratory field visits.

The questionnaire contained questions relevant to prone information about the petrol traders as well as on their ways of protecting themselves and their methods of storage. Data on the vendors' profile (districts of residency, marital status, level of education, main activities and secondary activities), the petrol commercialization, petrol storage, and incidents occurring during transportation or distributions, were collected during the surveys. Vendors' perceived health consequences emanating from prolonged exposure to counterfeit petrol were also documented. Data on the various storage locations, the types of losses encountered, cohabitation with petrol and the use of personal protective equipment were collected by observation. 


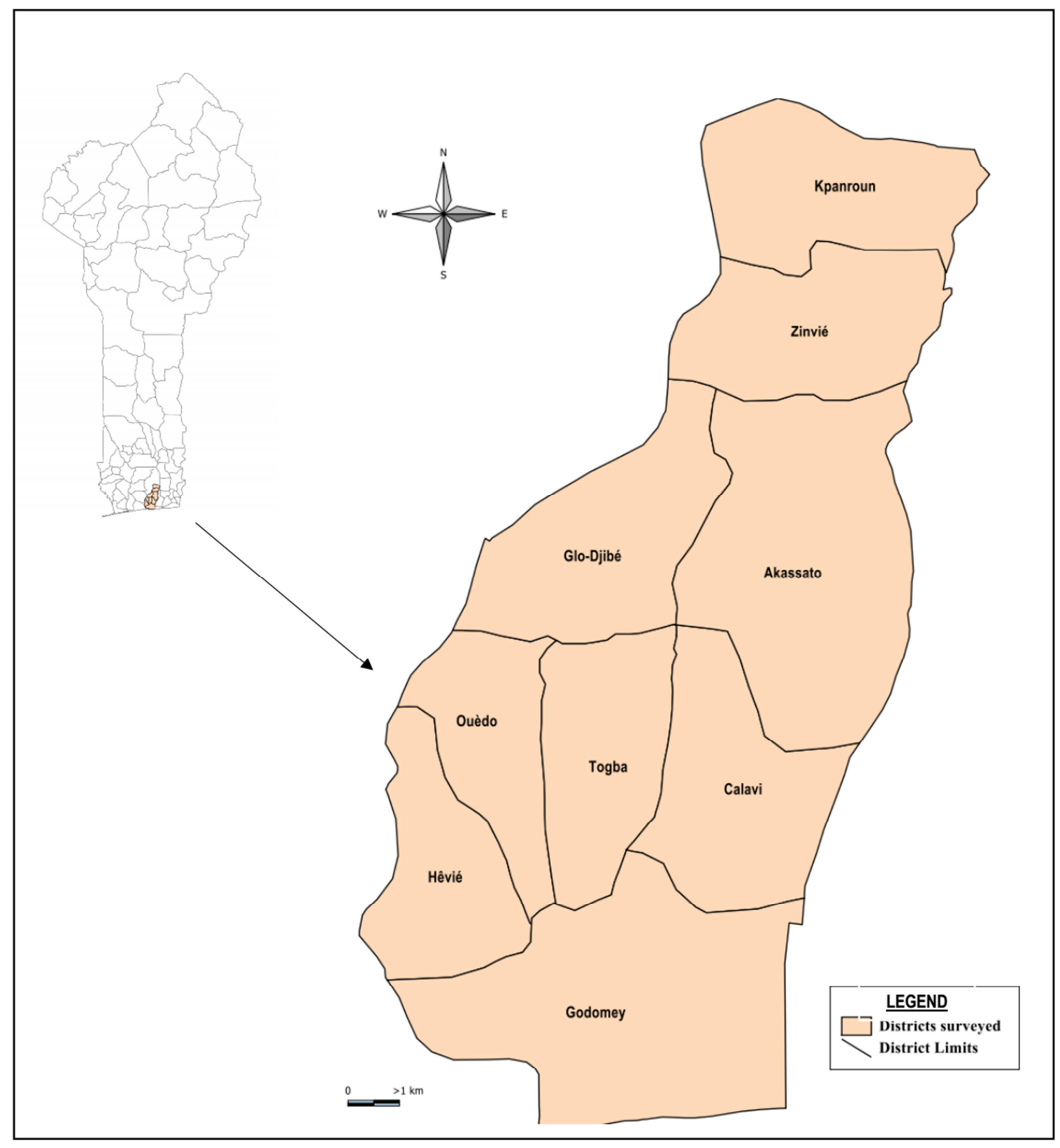

Figure 1. The commune of Abomey-Calavi and its major districts.

\subsection{Statistical Analysis}

The collected data were recorded in Excel and analyzed with SAS software (SAS Institute Inc., Cary, NC, USA). For the qualitative variables, the observed frequencies were calculated by the SAS Proc FREQ procedure. Comparison of the relative frequencies between the modalities and between gender was made by the two-tailed Z-test. For each relative frequency, a $95 \%$ confidence interval (CI) was calculated according to the formula:

$$
I C=1.96 \sqrt{\frac{P(1-P)}{N}}
$$

Where $\mathrm{P}$ is the relative frequency and $\mathrm{N}$ is the sample size. The CA function of the FactoMineR library of R was used for factorial correspondence analysis (FCA) $[18,19]$. The variables taken into account in the correspondence analysis are the use of protective equipment by the vendors, their districts, encountered incidents and clinical signs frequently experienced by the vendors. An ascending hierarchical classification (AHC) on the components of the FCA was then carried out and groups of vendors were identified.

\section{Results}

\subsection{Socio-professional Characteristics of the Surveyed Petrol Vendors}

Counterfeit petrol business owners in Abomey-Calavi were both men $(53.14 \%)$ and women $(46.89 \%)$ located mainly in 
central Abomey-Calavi (53.75\%, Table 1). The average age of the respondents was 36.58 years old and the women were older than the men (40.16 vs 33.42 years old, p 0.001 ). Respondents were mostly married with children (63.29\%), while a few were single without children (15.82\%), married without children $(8.23 \%)$, widows $(8.23 \%)$ and single with children $(4.43 \%)$. The proportion of married people with children was the highest $(p<0.05)$. Nevertheless, the proportion of single men without children was significantly higher than that of women and there were more widowers among the female respondents. A significantly high proportion of the surveyed vendors were people with no formal education $(45.91 \%, \mathrm{p}<0.05)$ compared to those with primary $(21.38 \%)$, secondary $(23.90 \%)$ and higher education $(8.81 \%)$. There were more of non-educated female vendors $(28,30 \%, \mathrm{p}<0,05)$ than men. On the other hand, the proportions of men with secondary $(16.35 \%)$ and university education $(6.92 \%)$ were significantly higher $(p<0.05)$ than those of women $(7.55 \%$ and $1.89 \%$, respectively). For most of the respondents $(73.42 \%)$ the petrol trade was their main activity. Other respondents do it as side job along with studies $(10.13 \%)$, general commerce $(6.33 \%)$, training $(4.43 \%)$, crafts $(2.53 \%)$, agriculture $(1.27 \%)$ and civil service $(1.27 \%)$. Overall, the activity of respondents does not vary between sex except for the proportion of male students $(7.59 \%)$ that was significantly higher $(\mathrm{p}<0.05)$ than in women $(2.53 \%)$.

The respondents got involved in this activity for various reasons. For the majority it was their main source of income $(34.62 \%$, significantly higher than the rest $\mathrm{p}<0.05)$. For some respondents it was an inherited business (23.08\%), some are doing it because of unemployment $(21.15 \%)$, or because they do not have any other skills (16.67\%) or lack sufficient funding to launch a different business (16.03\%). The reasons did not vary by sex except for the lack of business funds, which was more mentioned $(p<0.05)$ by the women (Table 1). These vendors had been in this business for 10.14 years with men being in it longer on average (11.64 years) than women ( 8.45 years).

Table 1. Characteristics of the investigated counterfeit fuel selling points.

\begin{tabular}{|c|c|c|c|c|c|c|}
\hline \multirow{2}{*}{ Variables } & \multicolumn{2}{|c|}{ General* } & \multicolumn{2}{|c|}{ Women** } & \multicolumn{2}{|l|}{ Men** } \\
\hline & $\%$ & CI & $\%$ & CI & $\%$ & CI \\
\hline \multicolumn{7}{|l|}{ Districts $(n=160)$} \\
\hline Calavi-centre & $53.75 \mathrm{a}$ & 7.73 & $30.00 \mathrm{a}$ & 7.10 & $23.75 a$ & 6.59 \\
\hline Akassato & $12.50 \mathrm{~b}$ & 5.12 & $6.25 \mathrm{a}$ & 3.75 & $6.25 \mathrm{a}$ & 3.75 \\
\hline Glodjigbé & $5.00 \mathrm{~cd}$ & 3.38 & $1.25 \mathrm{a}$ & 1.72 & $3.75 \mathrm{a}$ & 2.94 \\
\hline Godomey & $10.00 \mathrm{bc}$ & 4.65 & $4.38 \mathrm{a}$ & 3.17 & $5.63 \mathrm{a}$ & 3.57 \\
\hline Hêvié & $2.50 \mathrm{e}$ & 2.42 & $0.00 \mathrm{~b}$ & 0.00 & $2.50 \mathrm{a}$ & 2.42 \\
\hline Ouèdo & $4.38 \mathrm{de}$ & 3.17 & $0.63 \mathrm{a}$ & 1.23 & $3.75 \mathrm{a}$ & 2.94 \\
\hline Togba & $8.13 \mathrm{bcd}$ & 4.23 & $3.75 \mathrm{a}$ & 2.94 & $4.38 \mathrm{a}$ & 3.17 \\
\hline Zinvié & $2.50 \mathrm{e}$ & 2.42 & $0.00 \mathrm{~b}$ & 0.00 & $2.50 \mathrm{a}$ & 2.42 \\
\hline \multicolumn{7}{|l|}{ Marital situation $(n=158)$} \\
\hline Single without children & $15.82 b$ & 5.69 & $1.90 \mathrm{~b}$ & 2.13 & $13.92 \mathrm{a}$ & 5.40 \\
\hline Single with children & $4.43 \mathrm{c}$ & 3.21 & $1.90 \mathrm{a}$ & 2.13 & $2.53 \mathrm{a}$ & 2.45 \\
\hline Married without children & $8.23 \mathrm{c}$ & 4.29 & $3.80 \mathrm{a}$ & 2.98 & $4.43 \mathrm{a}$ & 3.21 \\
\hline Married with children & $63.29 \mathrm{a}$ & 7.52 & $30.38 \mathrm{a}$ & 7.17 & $32.91 \mathrm{a}$ & 7.33 \\
\hline \multicolumn{7}{|l|}{ Level of education $(n=159)$} \\
\hline Never been to school & $45.91 \mathrm{a}$ & 7.75 & $28.30 \mathrm{a}$ & 7.00 & $17.61 \mathrm{~b}$ & 5.92 \\
\hline Primary education & $21.38 \mathrm{~b}$ & 6.37 & $8.81 \mathrm{a}$ & 4.41 & $12.58 \mathrm{a}$ & 5.15 \\
\hline Secondary education & $23.90 \mathrm{~b}$ & 6.63 & $7.55 \mathrm{~b}$ & 4.11 & $16.35 \mathrm{a}$ & 5.75 \\
\hline Higher Education & $8.81 \mathrm{c}$ & 4.41 & $1.89 \mathrm{~b}$ & 2.12 & $6.92 \mathrm{a}$ & 3.94 \\
\hline \multicolumn{7}{|l|}{ Main activities $(\mathrm{n}=158)$} \\
\hline Petrol trade & $73.42 \mathrm{a}$ & 6.89 & $39.24 \mathrm{a}$ & 7.61 & $34.18 \mathrm{a}$ & 7.40 \\
\hline Student & $10.13 b$ & 4.70 & $2.53 b$ & 2.45 & $7.59 \mathrm{a}$ & 4.13 \\
\hline Trainee & $4.43 \mathrm{c}$ & 3.21 & $0.63 \mathrm{a}$ & 1.23 & $3.80 \mathrm{a}$ & 2.98 \\
\hline Farmer & $1.27 \mathrm{~d}$ & 1.75 & $0.00 \mathrm{a}$ & 0.00 & $1.27 \mathrm{a}$ & 1.75 \\
\hline General trader & $6.33 b c$ & 3.80 & $4.43 a$ & 3.21 & $1.90 \mathrm{a}$ & 2.45 \\
\hline Craftsman & $2.53 \mathrm{~cd}$ & 2.45 & $0.63 \mathrm{a}$ & 1.23 & $1.90 \mathrm{a}$ & 2.13 \\
\hline Civil servants & $1.27 \mathrm{~d}$ & 1.75 & $0.00 \mathrm{a}$ & 0.00 & $1.27 \mathrm{a}$ & 1.75 \\
\hline Others & $1.27 \mathrm{~d}$ & 1.75 & $0.00 \mathrm{a}$ & 0.00 & $1.27 \mathrm{a}$ & 1.75 \\
\hline \multicolumn{7}{|l|}{ Sales reasons $(n=156)$} \\
\hline Unemployment & $21.15 b$ & 6.41 & $9.62 \mathrm{a}$ & 4.63 & $11.54 \mathrm{a}$ & 5.01 \\
\hline Generate revenue & $34.62 \mathrm{a}$ & 7.47 & $16.27 \mathrm{a}$ & 5.79 & $17.95 \mathrm{a}$ & 6.02 \\
\hline Lack of Funding & $16.03 \mathrm{~b}$ & 5.76 & $12.82 \mathrm{a}$ & 5.25 & $3.21 \mathrm{~b}$ & 2.77 \\
\hline Other & $6.41 \mathrm{c}$ & 3.84 & $1.92 \mathrm{a}$ & 2.15 & $4.49 \mathrm{a}$ & 3.25 \\
\hline
\end{tabular}

CI: Confidence Interval, *: the intra-class percentages of the same column affected by different letters do differ at $95 \%$ level of significance; **: percentages of the same rows (men and women), followed by the same letters do not differ at the threshold of $95 \%$. 


\subsection{Characterization of the Fuel Commercialization Business}

Petrol is mostly sold at less than $400 \mathrm{~F}$ CFA per liter (97.47\%) sold petrol. A few respondents sold the liter at a price between $400 \mathrm{~F}$ CFA and $500 \mathrm{~F}$ CFA (3.16\%) but over $43 \%$ also mentioned more than $500 \mathrm{~F}$ CFA per liter (Table 2). Over $51 \%$ of the respondents mana make a profit of $1000 \mathrm{~F}$ to $5000 \mathrm{~F}$ per day, although some $19.62 \%$ of respondents made profits below $1000 \mathrm{~F}$ CFA, whereas $13.29 \%$ made between $5000 \mathrm{~F}$ CFA and $10.000 \mathrm{~F}$ CFA. The proportion of respondents whose profit was between $1000 \mathrm{~F}$ and $5000 \mathrm{~F}$ was significantly higher $(p<0.05)$ than the rest but did not vary significantly between men and women. On the other hand, the proportion of men who made more than $10.000 \mathrm{~F} \mathrm{CFA}$ $(12.03 \%)$ is significantly higher than the women $(3.80 \%)$. The quantity of petrol sold by most of the respondents per day was between 50 and 100 liters $(37.58 \%)$ and between 200 and 500 liters (36.94\%). The rest of the respondents sold less than 50 liters $(14.64 \%)$ and more than 500 liters $(10.90 \%)$. There were statistically more women who sell less than 50 liters of petrol per day and more men selling between 200 and 500 liters $(24.20 \%)$ per day compared to women (12.74\%). The sales were mostly made for 8 hours per day, but also for less than 8 hours (Table 3). Over $85 \%$ of the respondent worked more than 8 hours per day as compared to those who worked for 8 hours $(5.41 \%)$ or less. The proportion of men who worked 8 hours $(4.73 \%)$ per day was significantly higher than that of women $(0.68 \%)$ for the same duration. After these several hours of work, the majority of respondents $(64.83 \%)$ chose one day per week to rest.

Respondents recorded incidents such as inhalation $(82.84 \%)$, skin and / or mucosal contact (63.43\%) and petrol swallowing (54.48\%). The proportion of people who reported inhalation was significantly higher $(p<0.05)$ than vendors who reported skin and / or mucosal contact and petrol swallowing (Table 3). Between genders, petrol swallowing was more reported by males (33.58\%) than females $(20.90 \%)$.

The majority of respondents $(75.76 \%)$ did not use any protection when selling petrol (Table 4). The remaining minority protect themselves by wearing work clothes $(18.18 \%)$, gloves $(5.30 \%)$, helmet $(4.55 \%)$ and eyeglasses $(3.79 \%)$. People exposed to the petrol in their surroundings were women with their babies $(74.77 \%)$, pregnant women $(68.22 \%)$, children under $15(66.36 \%)$ and children under $5(57.01 \%)$. Pregnant women were mostly encountered $(\mathrm{p}<0.05)$ at sales points owned by men $(41.12 \%)$ than those of women $(27.10 \%)$.

Table 2. Petrol commercialization.

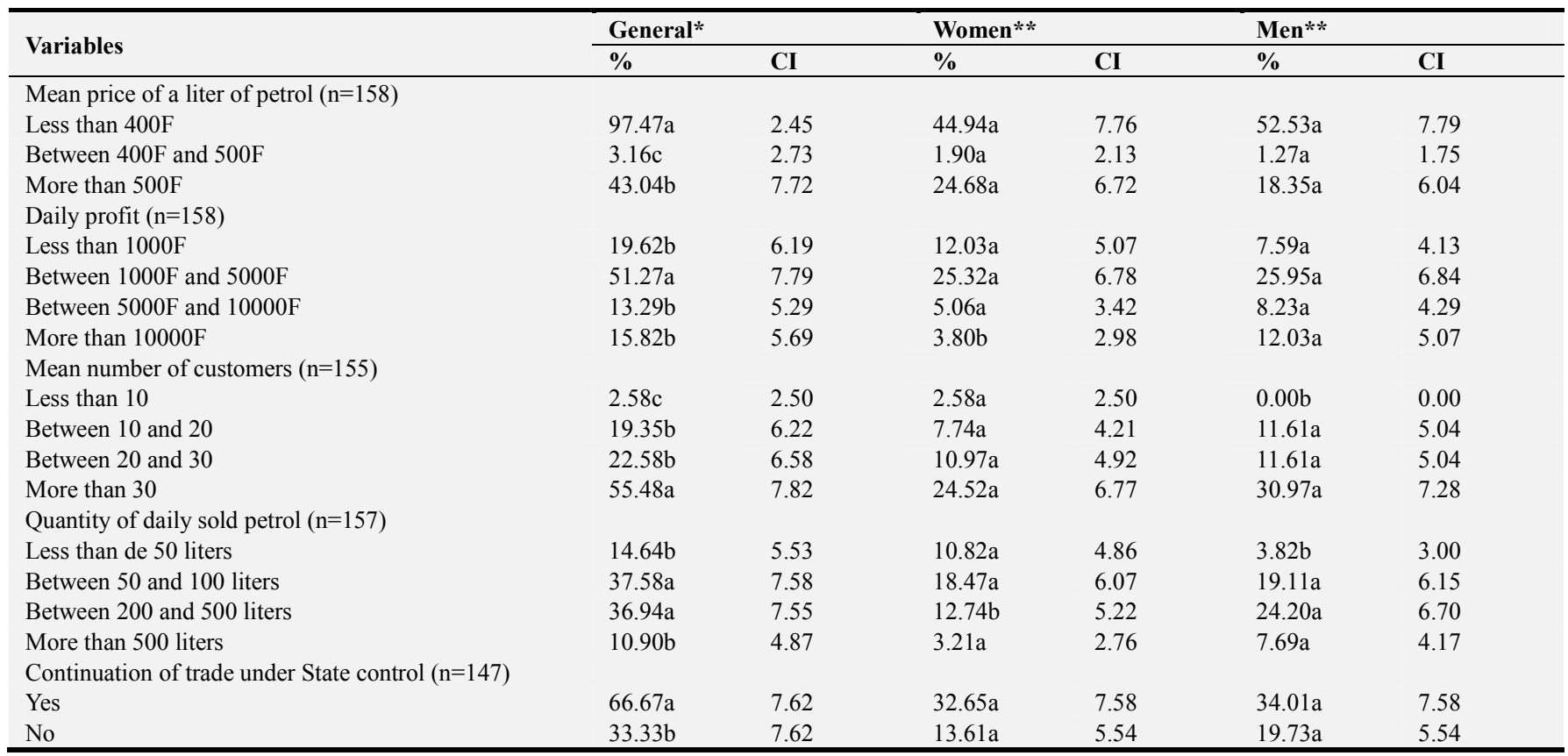

CI: Confidence Interval, *: the intra-class percentages of the same column affected by different letters do differ at $95 \%$ level of significance; **: percentages of the same rows (men and women), followed by the same letters do not differ at the threshold of $95 \%$.

Table 3. Working duration and encountered incidents.

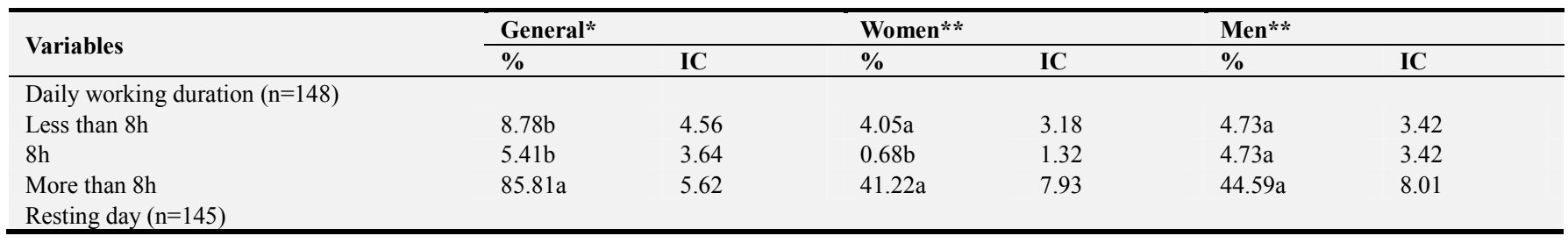




\begin{tabular}{|c|c|c|c|c|c|c|}
\hline \multirow{2}{*}{ Variables } & \multicolumn{2}{|c|}{ General* } & \multicolumn{2}{|c|}{ Women** } & \multicolumn{2}{|l|}{ Men** } \\
\hline & $\%$ & IC & $\%$ & IC & $\%$ & IC \\
\hline Yes & $64.83 b$ & 7.77 & $29.65 a$ & 7.43 & $35.18 \mathrm{a}$ & 7.77 \\
\hline No & $35.17 \mathrm{a}$ & 7.77 & $15.86 \mathrm{a}$ & 5.95 & $19.31 \mathrm{a}$ & 6.42 \\
\hline \multicolumn{7}{|c|}{ Incidents occurring during sales $(n=134)$} \\
\hline Inhalation & $82.84 \mathrm{a}$ & 6.38 & $36.57 \mathrm{a}$ & 8.15 & $46.27 \mathrm{a}$ & 8.44 \\
\hline Skin/mucosal contact & $63.43 b$ & 8.15 & $31.34 \mathrm{a}$ & 7.85 & $32.09 \mathrm{a}$ & 7.90 \\
\hline Swallowing of fuel & $54.48 b$ & 8.43 & $20.90 \mathrm{~b}$ & 6.88 & $33.58 \mathrm{a}$ & 8.00 \\
\hline No incident & $11.94 \mathrm{c}$ & 5.49 & $8.21 \mathrm{a}$ & 4.65 & $3.73 \mathrm{a}$ & 3.21 \\
\hline
\end{tabular}

CI: Confidence Interval, $*$ : the intra-class percentages of the same column affected by different letters do differ at $95 \%$ level of significance; $* *$ : percentages of the same rows (men and women), followed by the same letters do not differ at the threshold of $95 \%$.

Table 4. Protective measures.

\begin{tabular}{|c|c|c|c|c|c|c|}
\hline \multirow{2}{*}{ Variables } & \multicolumn{2}{|c|}{ General* } & \multicolumn{2}{|c|}{ Women** } & \multicolumn{2}{|l|}{ Men** } \\
\hline & $\%$ & CI & $\%$ & $\mathbf{C I}$ & $\%$ & CI \\
\hline \multicolumn{7}{|l|}{ Personal protective equipment $(\mathrm{n}=132)$} \\
\hline Gloves & $5.30 \mathrm{c}$ & 3.82 & $2.27 \mathrm{a}$ & 2.54 & $3.03 \mathrm{a}$ & 2.92 \\
\hline Special working clothes & $18.18 \mathrm{~b}$ & 6.58 & $9.09 \mathrm{a}$ & 4.90 & $9.09 \mathrm{a}$ & 4.90 \\
\hline Eyeglasses & $3.79 \mathrm{c}$ & 3.26 & $1.52 \mathrm{a}$ & 2.09 & $2.27 \mathrm{a}$ & 2.54 \\
\hline Other protective means & $3.03 \mathrm{c}$ & 2.92 & $1.52 \mathrm{a}$ & 2.09 & $1.51 \mathrm{a}$ & 2.08 \\
\hline \multicolumn{7}{|c|}{ Exposed people of the surrounding environment $(n=107)$} \\
\hline Pregnant female vendors & $68.22 \mathrm{ab}$ & 8.82 & $27.10 \mathrm{~b}$ & 8.42 & $41.12 \mathrm{a}$ & 9.32 \\
\hline Female vendors with children & $74.77 \mathrm{a}$ & 8.23 & $32.71 \mathrm{a}$ & 8.89 & $42.06 \mathrm{a}$ & 9.35 \\
\hline Children under 5 within $2 \mathrm{~m}$ of the point of sale & $57.01 \mathrm{~b}$ & 9.38 & $26.17 \mathrm{a}$ & 8.33 & $30.84 \mathrm{a}$ & 8.75 \\
\hline Children vendors of less than 15 y.o & $66.36 \mathrm{ab}$ & 8.95 & $32.71 \mathrm{a}$ & 8.89 & $33.64 \mathrm{a}$ & 8.95 \\
\hline
\end{tabular}

CI: Confidence Interval, $*$ : the intra-class percentages of the same column affected by different letters do differ at $95 \%$ level of significance; $* *$ : percentages of the same rows (men and women), followed by the same letters do not differ at the threshold of $95 \%$.

\subsection{Storage Practices and Losses}

The petrol sold is stored at the point of sale and at home. The proportion of those who store exclusively at the point of sale $(57.25 \%)$ was significantly higher $(p<0.05)$ than those who store at home. When stored at home, men cohabited with petrol in $48.15 \%$ of cases. The majority of respondents (93.28\%) stored petrol in closed containers. Despite the provision made for the storage, losses were reported in $75 \%$ of the sales shops visited (Table 5). These losses were mainly due to spillovers $(94.02 \%)$.

Table 5. Storage and losses.

\begin{tabular}{|c|c|c|c|c|c|c|}
\hline \multirow{2}{*}{ Variables } & \multicolumn{2}{|c|}{ General* } & \multicolumn{2}{|c|}{ Women** } & \multicolumn{2}{|l|}{ Men** } \\
\hline & $\%$ & CI & $\%$ & CI & $\%$ & CI \\
\hline \multicolumn{7}{|l|}{ Place of storage $(n=138)$} \\
\hline At home & $23.19 b$ & 7.04 & $9.42 \mathrm{a}$ & 4.87 & $13.77 \mathrm{a}$ & 5.75 \\
\hline At the point of sale & $57.25 \mathrm{a}$ & 8.25 & $28.26 \mathrm{a}$ & 7.51 & $28.99 \mathrm{a}$ & 7.57 \\
\hline Both of the above & $19.56 b$ & 6.62 & $9.42 \mathrm{a}$ & 4.87 & $10.14 \mathrm{a}$ & 5.04 \\
\hline \multicolumn{7}{|l|}{ Storage containers $(n=134)$} \\
\hline Closed & $93.28 \mathrm{a}$ & 4.24 & $42.54 \mathrm{a}$ & 8.37 & $50.74 a$ & 8.46 \\
\hline \multicolumn{7}{|l|}{ Past accidental losses $(n=157)$} \\
\hline Yes & $75.80 \mathrm{a}$ & 6.70 & $34.39 \mathrm{a}$ & 7.43 & $41.40 \mathrm{a}$ & 7.70 \\
\hline No & $24.20 \mathrm{~b}$ & 6.70 & $11.46 \mathrm{a}$ & 4.98 & $12.74 \mathrm{a}$ & 5.22 \\
\hline \multicolumn{7}{|l|}{ Type of loss $(n=117)$} \\
\hline Spillover on the floor & $94.02 \mathrm{a}$ & 4.30 & $45.30 \mathrm{a}$ & 9.02 & $48.72 \mathrm{a}$ & 9.06 \\
\hline $\begin{array}{l}\text { Spillover in the lake/river during transport } \\
\text { Cohabitation with fuel }(n=54)\end{array}$ & $20.51 b$ & 7.32 & $2.56 \mathrm{~b}$ & 2.86 & $17.95 \mathrm{a}$ & 6.95 \\
\hline No cohabitation & $51.85 \mathrm{a}$ & 13.33 & $27.78 \mathrm{a}$ & 11.95 & $24.07 \mathrm{a}$ & 11.40 \\
\hline
\end{tabular}

CI: Confidence Interval, *: the intra-class percentages of the same column affected by different letters do differ at $95 \%$ level of significance; $* *$ : percentages of the same rows (men and women), followed by the same letters do not differ at the threshold of $95 \%$.

\subsection{Occupational Health Risks Associated with Petrol Trade}

The respondents suffered from various underlining predisposing health conditions including cardiovascular diseases $(24.44 \%)$, pulmonary cases $(24.44 \%)$, sinusitis $(42.22 \%)$ and others $(35.56 \%)$.

The majority of respondents $(90.60 \%)$ acknowledged that 
petrol has harmful consequences on their health. The perceived consequences were diverse, but the commonly cited were fatigue $(71.67 \%)$, headache $(58.21 \%)$ and dizziness $(51.49 \%)$ (Table 7$)$. The proportion of men $(42.51 \%)$ who reported fatigue was significantly higher ( $p$ $<0.05)$ than that of women $(29.1 \%)$. Other effects such as sleepiness (31\%), chest pain (40\%), cough (49\%), palpitations $(19 \%)$, nausea or vomiting $(28 \%)$, eye irritation $(43 \%)$ and skin rashes $(8 \%)$ as well as abdominal $(41 \%)$ and back pain $(2 \%)$ were listed.

The symptoms frequently experienced by the vendors are presented in Table 8 . The symptoms reported as being frequently experienced were mostly fatigue (82.76\%), headache $(66.21 \%)$, dizziness $(60.69 \%)$ and skin irritation $(51.03 \%)$. The proportion of people reporting fatigue was significantly higher $(\mathrm{p}<0.05)$ than for all other symptoms.

The most reported respiratory symptoms were sneezing $(69.92 \%)$, stuffy nose $(68.42 \%)$, loss of smell $(55.64 \%)$, episodes of rhinorrhea $(53.38 \%)$ and throat irritation $(51.88 \%)$. The proportions of people reporting sneezing and stuffy nose were more common $(\mathrm{p}<0.05)$ (Table 9). The rhinorrhea was more benign $(56.72 \%)$, purulent $(53.73 \%)$ than bloody $(1.49 \%)$. Loss of smell was reported more in males (33.83\%) than females $(21.80 \%)$. On the other hand, breathing difficulties were more reported in women (26.32\%) than men (18.80\%).

Overall, very few people $(16.67 \%)$ seek medical care when affected by petrol related health consequences. The significant majority ( $84 \%$ ) of people who did consult medical personnel did so in health centers while some (25\%) consulted with traditional healers (Table 8). Once in the hospital, the vendors underwent two types of check-ups: $\mathrm{x}$ - rays and blood tests. Blood tests were more frequent than $\mathrm{x}$ rays $(78.57 \%$ vs $35.71 \%$; $<<0.05)$.

Besides health consequences, street petrol vendors were sometimes subjected to repression from the government given the informal nature of their activity and the fires that it causes $(6.45 \%)$. These pressures did not however discourage the majority of respondents $(66.67 \%)$ who were not ready to stop the business. But when it comes to health challenges, the majority $(73.20 \%)$ of them wished to change activities.

Three axes were retained for the interpretation of the results of the factorial correspondence analysis (FCA) $\left(\chi^{2}=\right.$ 117.83). These three axes represent $66.90 \%$ of the data, including $31.23 \%$ on the first axis, $24.38 \%$ on the second axis and $11.29 \%$ on the third axis. Each axis corresponds to a group of petrol vendors. Figure 2 shows the results of the factorial correspondence analysis.

Group 1 is characterized by vendors from Glo-Djibé, Hèvié and Kpanroun. These people mostly reported petrol swallowing as an incident. Frequently reported symptoms were dizziness, irritation of the eyes, loss of smell, and bleeding from the nose.

Group 2 is made of vendors from Akassato and Zinvié. They wear gloves, clothing, goggles and helmets to protect themselves from petrol. However, they reported petrol inhalation and skin contact as an incident. Commonly reported symptoms were episodes of rhinorrhea and irritation of the throat.

Group 3 is composed of vendors from Godomey, Calavi, Togba and Ouédo. They do not wear any protective gear. Symptoms include headache, fatigue, sleepiness, chest pain, nausea, lower back pain, stuffy nose and dental problems.

Table 6. Underlining health conditions.

\begin{tabular}{|c|c|c|c|c|c|c|}
\hline \multirow{2}{*}{ Underling conditions $(n=45)$} & \multicolumn{2}{|c|}{ General* } & \multicolumn{2}{|c|}{ Women** } & \multicolumn{2}{|l|}{ Men** } \\
\hline & $\%$ & CI & $\%$ & $\%$ & $\mathbf{C I}$ & $\%$ \\
\hline Cardio-vascular & $24.44 a$ & 12.56 & $13.33 \mathrm{a}$ & 9.93 & $11.11 \mathrm{a}$ & 9.18 \\
\hline Pulmonary & $24.44 \mathrm{a}$ & 12.56 & $13.33 \mathrm{a}$ & 9.93 & $11.11 \mathrm{a}$ & 9.18 \\
\hline Sinusitis & $42.22 \mathrm{a}$ & 14.43 & $15.56 \mathrm{a}$ & 10.59 & $26.67 \mathrm{a}$ & 12.92 \\
\hline Others & $35.56 \mathrm{a}$ & 13.99 & $11.11 \mathrm{a}$ & 9.18 & $24.44 \mathrm{a}$ & 12.56 \\
\hline
\end{tabular}

CI: Confidence Interval, *: the intra-class percentages of the same column affected by different letters do differ at $95 \%$ level of significance; $* *$ : percentages of the same rows (men and women), followed by the same letters do not differ at the threshold of $95 \%$.

Table 7. Level of awareness in petrol vendors on health consequences and related symptoms.

\begin{tabular}{|c|c|c|c|c|c|c|}
\hline \multirow{2}{*}{ Variables } & \multicolumn{2}{|c|}{ General* } & \multicolumn{2}{|c|}{ Women** } & \multicolumn{2}{|l|}{ Men** } \\
\hline & $\%$ & CI & $\%$ & $\%$ & CI & $\%$ \\
\hline \multicolumn{7}{|c|}{ Awareness of health consequences posed by counterfeit petrol $(n=149)$} \\
\hline Yes & $90.60 \mathrm{a}$ & 4.69 & $42.28 \mathrm{a}$ & 7.93 & $48.32 \mathrm{a}$ & 7.93 \\
\hline No & $9.40 \mathrm{~b}$ & 4.69 & $2.68 \mathrm{a}$ & 2.59 & $6.71 \mathrm{a}$ & 2.59 \\
\hline \multicolumn{7}{|c|}{ Known consequences $(n=134)$} \\
\hline Headache & $58.21 \mathrm{~b}$ & 8.35 & $31.34 \mathrm{a}$ & 7.85 & $26.87 \mathrm{a}$ & 7.51 \\
\hline Dizziness & $51.49 b c$ & 8.46 & $26.12 \mathrm{a}$ & 7.44 & $25.37 \mathrm{a}$ & 7.37 \\
\hline Fatigue & $71.64 \mathrm{a}$ & 7.63 & $29.10 \mathrm{~b}$ & 7.69 & $42.51 \mathrm{a}$ & 8.37 \\
\hline Sleepiness & $30.60 \mathrm{de}$ & 7.80 & $14.93 \mathrm{a}$ & 6.03 & $15.67 \mathrm{a}$ & 6.16 \\
\hline Chest pain & $40.30 \mathrm{~cd}$ & 8.31 & $15.67 \mathrm{~b}$ & 6.16 & $24.63 a$ & 7.30 \\
\hline Cough & $48.51 b c$ & 8.46 & $26.87 \mathrm{a}$ & 7.51 & $21.64 \mathrm{a}$ & 6.97 \\
\hline Palpitations & $19.40 \mathrm{f}$ & 6.70 & $10.45 a$ & 5.18 & $8.96 \mathrm{a}$ & 4.84 \\
\hline Nausea and vomiting & $27.61 \mathrm{ef}$ & 7.57 & $16.42 \mathrm{a}$ & 6.27 & $11.19 \mathrm{a}$ & 5.34 \\
\hline Eye irritation & $43.28 c$ & 8.39 & $21.64 \mathrm{a}$ & 6.97 & $21.64 \mathrm{a}$ & 6.97 \\
\hline Skin irritation & $41.04 \mathrm{~cd}$ & 8.33 & $20.90 \mathrm{a}$ & 6.88 & $20.15 a$ & 6.79 \\
\hline No symptom & $2.24 \mathrm{~h}$ & 2.51 & $0.75 \mathrm{a}$ & 1.46 & $1.49 \mathrm{a}$ & 2.05 \\
\hline
\end{tabular}




\begin{tabular}{|c|c|c|c|c|c|c|}
\hline \multirow{2}{*}{ Variables } & \multicolumn{2}{|c|}{ General* } & \multicolumn{2}{|c|}{ Women** } & \multicolumn{2}{|c|}{ Men** } \\
\hline & $\%$ & CI & $\%$ & $\%$ & CI & $\%$ \\
\hline Others & $8.21 \mathrm{~g}$ & 4.65 & $2.99 \mathrm{a}$ & 2.88 & $5.22 \mathrm{a}$ & 3.77 \\
\hline
\end{tabular}

CI: Confidence Interval, *: the intra-class percentages of the same column affected by different letters do differ at $95 \%$ level of significance; **: percentages of the same rows (men and women), followed by the same letters do not differ at the threshold of $95 \%$.

Table 8. Declared health consequences due to exposure to petrol and treatment options.

\begin{tabular}{|c|c|c|c|c|c|c|}
\hline \multirow{2}{*}{ Variables } & \multicolumn{2}{|l|}{ General* } & \multicolumn{2}{|c|}{ Women** } & \multicolumn{2}{|l|}{ Men** } \\
\hline & $\%$ & CI & $\%$ & $\%$ & CI & $\%$ \\
\hline \multicolumn{7}{|c|}{ Frequently felt symptoms $(\mathrm{n}=145)$} \\
\hline Headache & $66.21 \mathrm{~b}$ & 7.70 & $32.41 \mathrm{a}$ & 7.62 & $33.79 \mathrm{a}$ & 7.70 \\
\hline Dizziness & $60.69 b c$ & 7.95 & $31.03 \mathrm{a}$ & 7.53 & $29.66 \mathrm{a}$ & 7.43 \\
\hline Fatigue & $82.76 \mathrm{a}$ & 6.15 & $38.62 \mathrm{a}$ & 7.92 & $44.14 \mathrm{a}$ & 8.08 \\
\hline Sleepiness & $47.22 \mathrm{~d}$ & 8.13 & $22.76 \mathrm{a}$ & 6.82 & $25.52 \mathrm{a}$ & 7.10 \\
\hline Chest pain & $48.28 \mathrm{~d}$ & 8.13 & $22.45 \mathrm{a}$ & 6.79 & $25.17 \mathrm{a}$ & 7.06 \\
\hline Cough & $48.28 \mathrm{~d}$ & 8.13 & $23.45 \mathrm{a}$ & 6.90 & $24.83 a$ & 7.03 \\
\hline Palpitations & $26.90 \mathrm{e}$ & 7.22 & $17.24 \mathrm{a}$ & 6.15 & $9.66 \mathrm{a}$ & 4.81 \\
\hline Nausea or vomiting & $22.07 \mathrm{e}$ & 6.75 & $12.41 \mathrm{a}$ & 5.37 & $9.66 \mathrm{a}$ & 4.81 \\
\hline Irritation of the eyes & $48.97 \mathrm{~cd}$ & 8.14 & $26.90 \mathrm{a}$ & 7.22 & $22.07 \mathrm{a}$ & 6.75 \\
\hline Abdominal pain & $11.03 \mathrm{fg}$ & 5.10 & $7.59 \mathrm{a}$ & 4.31 & $3.45 \mathrm{a}$ & 2.97 \\
\hline Back pain & $17.93 \mathrm{f}$ & 6.24 & $11.72 \mathrm{a}$ & 5.24 & $6.21 \mathrm{a}$ & 3.93 \\
\hline Skin irritation & $51.03 \mathrm{~cd}$ & 8.14 & $27.59 \mathrm{a}$ & 7.28 & $23.45 \mathrm{a}$ & 6.90 \\
\hline No symptoms & $1.38 \mathrm{~h}$ & 1.90 & $0.69 \mathrm{a}$ & 1.35 & $0.69 \mathrm{a}$ & 1.35 \\
\hline Others & $8.28 \mathrm{~g}$ & 4.49 & $2.07 \mathrm{a}$ & 2.32 & $6.21 \mathrm{a}$ & 3.93 \\
\hline \multicolumn{7}{|l|}{ Medical care $(\mathrm{n}=144)$} \\
\hline Yes & $16.67 \mathrm{~b}$ & 6.09 & $7.64 \mathrm{a}$ & 4.34 & $9.03 \mathrm{a}$ & 4.68 \\
\hline No & $83.33 \mathrm{a}$ & 6.09 & $38.19 a$ & 7.94 & $45.14 \mathrm{a}$ & 8.13 \\
\hline \multicolumn{7}{|l|}{ Place of care $(n=25)$} \\
\hline Health center & $84.00 \mathrm{a}$ & 14.37 & $40.00 \mathrm{a}$ & 19.20 & $44.00 \mathrm{a}$ & 19.46 \\
\hline Traditional healers & $20.00 \mathrm{~b}$ & 15.68 & $8.00 \mathrm{a}$ & 10.63 & $12.00 \mathrm{a}$ & 12.74 \\
\hline \multicolumn{7}{|c|}{ Tests during medical consultation $(n=14)$} \\
\hline x-ray & $35.71 \mathrm{~b}$ & 25.10 & $14.29 \mathrm{a}$ & 18.33 & $21.42 \mathrm{a}$ & 21.49 \\
\hline Blood test & $78.57 \mathrm{a}$ & 21.19 & $42.86 \mathrm{a}$ & 25.92 & $35.65 \mathrm{a}$ & 25.09 \\
\hline \multicolumn{7}{|c|}{ Consider changing profession $(\mathrm{n}=153)$} \\
\hline Yes & $73.20 \mathrm{a}$ & 7.02 & $34.64 a$ & 7.54 & $38.56 \mathrm{a}$ & 7.71 \\
\hline No & $26.80 \mathrm{~b}$ & 7.02 & $10.46 a$ & 4.85 & $16.34 \mathrm{a}$ & 5.86 \\
\hline \multicolumn{7}{|l|}{ Victim of fire $(n=155)$} \\
\hline Yes & $6.45 \mathrm{~b}$ & 3.87 & $0.64 \mathrm{~b}$ & 1.26 & $5.81 \mathrm{a}$ & 3.68 \\
\hline No & $93.55 \mathrm{a}$ & 3.87 & $45.16 \mathrm{a}$ & 7.83 & $48.39 \mathrm{a}$ & 7.87 \\
\hline
\end{tabular}

CI: Confidence Interval, *: the intra-class percentages of the same column affected by different letters do differ at $95 \%$ level of significance; **: percentages of the same rows (men and women), followed by the same letters do not differ at the threshold of $95 \%$.

Table 9. Respiratory symptoms.

\begin{tabular}{|c|c|c|c|c|c|c|}
\hline \multirow{2}{*}{ Variables } & \multicolumn{2}{|l|}{ General* } & \multicolumn{2}{|c|}{ Women** } & \multicolumn{2}{|l|}{ Men** } \\
\hline & $\%$ & CI & $\%$ & $\%$ & CI & $\%$ \\
\hline \multicolumn{7}{|l|}{ Cited respiratory symptoms $(\mathrm{n}=133)$} \\
\hline Sneezing & $69.92 \mathrm{a}$ & 7.79 & $38.35 \mathrm{a}$ & 8.26 & $31.58 \mathrm{a}$ & 7.90 \\
\hline Stuffy nose & $68.42 \mathrm{a}$ & 7.90 & $34.59 \mathrm{a}$ & 8.08 & $33.83 \mathrm{a}$ & 8.04 \\
\hline Loss of smell & $55.64 \mathrm{~b}$ & 8.44 & $21.80 \mathrm{a}$ & 7.02 & $33.83 \mathrm{~b}$ & 8.04 \\
\hline Bleeding from the nose & $8.27 f$ & 4.68 & $3.23 \mathrm{a}$ & 3.00 & $5.65 \mathrm{a}$ & 3.92 \\
\hline Throat irritations & $51.88 \mathrm{~b}$ & 8.49 & $28.57 \mathrm{a}$ & 7.68 & $23.31 \mathrm{a}$ & 7.19 \\
\hline Dental affections & $51.88 \mathrm{~b}$ & 8.49 & $21.05 \mathrm{a}$ & 6.93 & $30.83 \mathrm{a}$ & 7.85 \\
\hline Continuous cough of up to a year & $15.79 \mathrm{e}$ & 6.20 & $9.77 \mathrm{a}$ & 5.05 & $6.02 \mathrm{a}$ & 4.04 \\
\hline Need to expectorate in the morning & $36.09 \mathrm{~cd}$ & 8.16 & $19.55 \mathrm{a}$ & 6.74 & $16.54 \mathrm{a}$ & 6.31 \\
\hline Need to expectorate day and night & $33.83 d$ & 8.04 & $15.79 \mathrm{a}$ & 6.20 & $18.04 \mathrm{a}$ & 6.54 \\
\hline Breathing difficulties & $45.11 \mathrm{bcd}$ & 8.46 & $26.32 \mathrm{a}$ & 7.48 & $18.80 \mathrm{~b}$ & 6.64 \\
\hline Heavy breathing when walking & $45.11 \mathrm{bcd}$ & 8.46 & $26.32 \mathrm{a}$ & 7.48 & $18.80 \mathrm{~b}$ & 6.64 \\
\hline Episodes of rhinorrhea & $53.38 \mathrm{~b}$ & 8.48 & $30.83 a$ & 7.85 & $22.55 \mathrm{a}$ & 7.10 \\
\hline \multicolumn{7}{|l|}{ Aspects of the rhinorrhea $(n=67)$} \\
\hline Purulent & $53.73 \mathrm{a}$ & 11.94 & $29.85 \mathrm{a}$ & 10.96 & $23.88 \mathrm{a}$ & 10.21 \\
\hline Bloody & $1.49 \mathrm{~b}$ & 2.90 & $1.49 \mathrm{a}$ & 2.90 & $0.00 \mathrm{a}$ & 0.00 \\
\hline Benign & $56.72 \mathrm{a}$ & 11.86 & $34.33 \mathrm{a}$ & 11.37 & $22.39 \mathrm{a}$ & 9.98 \\
\hline
\end{tabular}

CI: Confidence Interval, *: the intra-class percentages of the same column affected by different letters do differ at $95 \%$ level of significance; **: percentages of the same rows (men and women), followed by the same letters do note differ at the threshold of $95 \%$. 


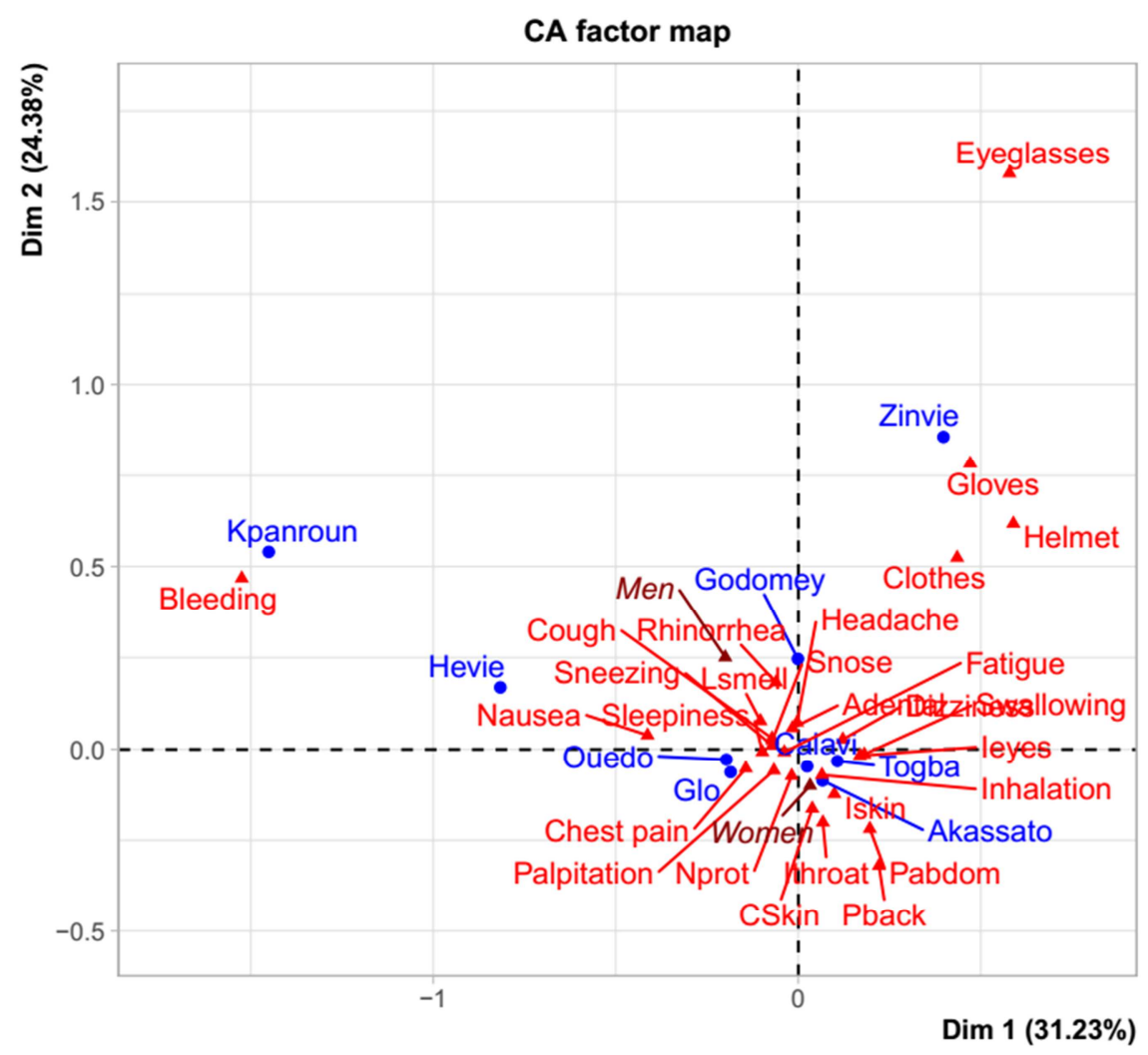

Figure 2. Spatial distribution of reported clinical signs by districts of residency (Lsmell: Loss of smell; IThroat: Throat irritations; Pback: Back pain; Iskin: Skin irritation; Ieyes: Irritation of the eyes; Pabdom: Abdominal pain; CSkin: Skin/mucosal contact; Nprot: No protection; Snose: Stuffy nose).

\section{Discussion}

\subsection{Socio-professional Characteristics of Petrol Vendors}

Counterfeit petrol vendors were present in all the districts of the municipality of Abomey-Calavi, as this business is present in every street across the country [4]. This widespread of the business of kpayo could be linked to the high demand and above all to its informal nature. The demographic growth, the increased diversity in economic activities, the development of industries and transportations continuously increase the demand for petroleum products. Formal petrol stations often fail to meet demands and the gap is filled by the informal sector. The non-tax-payment in the informal sector reduces the selling price of their product to the benefit of vendors and consumers who pay less than at a formal petrol stations [20]. The lower price of kpayo makes it more affordable to consumers compared to the genuine petrol from stations and thus the counterfeit activity became a blooming business, although, this informality generates economic losses for the government [4, 20]. The vendors of kpayo were mostly married people with children and no alternative sources of income. They therefore have family responsibilities that only the counterfeit activity could help them alleviate [2]. The income from this activity had already been presented as a source of financial stability for women by Montcho and Amouzouvi [2] and this explains the involvement of women as well as men in this business in Abomey-Calavi. Most of the vendors did not have a formal education confirming a previous report by Eloundou [21] in Cameroun. However, some educated men were interested in this activity because of the relatively high income that it provides to circumvent unemployment issues and to support livelihood.

\subsection{Characteristics of the Counterfeit Petrol Business}

Kpayo was mostly sold at 400 F CFA per liter and similar prices were reported by Montcho and Amouzouvi [2] with 375 F CFA in Cotonou. This is slightly lower than the price oscillating between 425 and $475 \mathrm{~F}$ CFA reported by Eloundou [21] in Cameroon. The selling price of kpayo is often lower than the genuine petrol from stations with differences ranging between 37 and 149 F CFA [20]. However, the price of kpayo varies according to the fluctuation of the exchange rate of Naira [20, 22, 23] and border repressions by the authorities in Benin and Nigeria. The price of kpayo is set by the union of kpayo vendors, and the price sometimes differs between unions. With the closure of the Nigeria-Benin borders since August 2019, the selling price of kpayo fluctuates between 400 and $500 \mathrm{~F}$ CFA. The daily profits ranges between 1000 to $5000 \mathrm{~F}$ per day (or 30,000 to 150,000 F CFA per month). Daily profits of $2414 \mathrm{~F}$ CFA [3] and 5000 F CFA were previously reported in Benin [2]. The benefit from kpayo could exceed 10.000 FCFA in rare cases mostly among wholesalers. Given this high income, the wholesalers were structured in strong associations, with a national cartel which allows them to control prices on a daily basis from all retailers [4]. The profit made allows the sellers 
to bear the household expenses as already suggested in previous studies [2] and this encourages them to continue the business despite government repressions. To make such a profit, the vendors had to work more than 8 hours a day and 6 days a week. The long working hours justify the recurrent fatigue often felt by the respondents. The high number of working days is associated with an increased risk of occurrence of back pain and respiratory symptoms, eye irritations and neurological issues mostly encountered in women [7].

\subsection{Exposure to Fuel}

The incidents often reported by the vendors were inhalation, skin contact and petrol swallowing because they were not protecting themselves enough and to fill the bottles, they often sucked petrol with their mouths. This lack of protective measures, especially protective masks, is associated with skin lesions, headaches and neurological symptoms. [7]. The lack of protection is linked to the low level of education of the respondents mostly unaware of the importance of these protective measures. The most sensitive incident is inhalation as reported by Adeothy-Koumakpaï et al. [9] in Benin. The risk of benzene poisoning was therefore present, and vendors tend to develop respiratory ailments. Prolonged exposure to this substance can cause biochemical (increase in serum lead and cadmium levels and decrease in copper, zinc, iron and glutathione content) and immunological disorders (decrease in IgA, IgG and increase in $\operatorname{IgM}$ ) and oxidative stress [24, 25]. It also causes the expression of the tumor suppressor p53 gene in petrol vendors which accelerates the loss of anti-tumorigenic activity in cells [25]. These effects of inhaling fuel are more harmful in young people who develop acute leukemia over time [26, 27] and vendors should take measures to avoid the presence of children in their surroundings.

\subsection{Storage and Losses}

Kpayo is mainly stored at the point of sale to facilitate withdrawal in the event of a breakage. However, home storage was reported by some respondents and exposes their family to the risk of inhalation with its consequences including fires [21]. Eloundou [21] linked the lack of standards required for storage with low level of education among vendors. The shortcomings observed in the inadequate storage of petrol caused losses and it was often spilled on the ground, which constitutes a fire risk especially if the vendor is a smoker or is visited by smokers. Male vendors recorded more losses during transportation on the river. The petrol poured into rivers is a public health problem because the heavy metals (lead, cadmium, etc.) in it can be accumulated in various tissues of fish and crabs intended for human consumption [28-30].

\subsection{Health Related Consequences Due to Exposure to Petrol}

The commonly reported clinical signs such as fatigue, cough, itchy eyes, nausea, vomiting, abdominal pain, skin irritation, and headache or headache, corroborate those previously reported by other researchers [7, 8, 31]. Other symptoms such as skin tumor, migraine, fainting, diarrhea and runny nose have been reported in people exposed to petroleum products $[8,31]$. The fatigue reported by the respondents may not be pathological but rather due to the long working hours which goes beyond 8 hours per day. The same observation was made by Rashid et al. [31] who advocated for the reduction of working hours by petrol vendors in order to preserve their health. Neurasthenic symptoms like insomnia and fainting are reported as excessive working hour related [31].

Apart from these symptoms, the vendors were also confronted with respiratory symptoms. The implication of petrol in respiratory symptoms has already been reported by Syimir Fizal et al. [32] in Malaysia. Petrol generates particles of $0.02 \mathrm{~nm}$ in diameter which are deposited in the bronchioles, causing inflammation of the airways [12] at the root of most of these respiratory symptoms. The toxic chemicals in the petrol can enter the bloodstream through the lungs, also affecting other organs including the heart, liver, kidneys and the nervous system [13]. The action of petrol on the central nervous system results in depression, hallucinations, delirium, loss of consciousness, convulsions and euphoria [12, 13]. Most of these nervous symptoms were not reported in this study because it would be difficult for vendors to assess their mental health on their own.

Apart from the skin, and respiratory lesions, a high risk of cancer caused by benzene, cytotoxicity and genotoxicity affecting the integrity of DNA in petrol station workers have been reported [33-37]. The consequences of petrol on the health of vendors vary depending on the length of exposure and become more dangerous for those who have spent several years in this business [38]. The effects of exposure to fuel would be more important among kpayo vendors given the storage and distribution methods that put them in constant contact with the product. Vendors therefore need to take the necessary protective measures, especially since they rarely consult doctors.

\section{Conclusion}

The study shows that the sale of kpayo generates significant income. Unfortunately, the handling conditions and storage practices of this petroleum product expose the vendors to various health and safety hazards. Health hazards result in the presentation of physical, cutaneous and respiratory symptoms, followed by safety damages by fires. The vendors are not unaware of these dangers but the lack of employment forces them to continue this activity. To safeguard the health of these vendors, it is essential to sensitize them on the importance of improved storage, reduced working hours per day and improvement of protection in the workplace. Some vendors are more physiologically vulnerable to exposure to toxic elements and are less able to communicate their concerns or medical needs. It is therefore essential to carry out a more in-depth 
actionable and biological research on health consequences associated to prolonged exposure to petrol in Benin.

\section{Ethical Approval}

The study was approved by the National Committee of Ethics for Health Research (CNERS).

\section{Acknowledgements}

The authors also thank Dr. Yaovi M. Gildas Hounmanou for his help in translating this manuscript into English.

\section{References}

[1] Ale A. Economie Informelle et Emploi au Bénin : Cadre et Pratiques de l'Economie Informelle dans 03 secteurs d'activités à Cotonou. 2011.

[2] Montcho B, Amouzouvi D. Commercialisation de l'essence "Kpayo" à Cotonou : une solution à la disqualification sociale. Les Cah Du CELHTO 2015; 1: 271-194. https://doi.org/10.5897/ERR2015.

[3] Agossou N. Dynamique spatiale à Porto-Novo: les effets de la diffusion des produits pétroliers kpayo. Espac Géographique 2004; 33: 211-218.

[4] Eyebiyi E. Étudier l'État à partir de l'informalité. Répression et résistances autour du commerce informel de carburant. Lien Soc Polit 2016; 76: 77-95. https://doi.org/10.7202/1037066ar.

[5] Dougnon T, Laleye A, Degnon R. Evaluation des effets bilogiques de l'inhalation de vapeurs d'essence sur l'hemmogramme, le poumon et le rein du rat albinos Wistar. Bull La Rech Agron Du Bénin 2014; 75: 39-46.

[6] Lee C, Kang Y, Chang K, Kim C, Hur J, Kim J, et al. Acute Health Effects of the Hebei Oil Spill on the Residents of Taean, Korea. J Prev Med Public Heal 2010; 43: 166-173. https://doi.org/10.3961/jpmph.2010.43.2.166.

[7] Sim MS, Jo IJ, Song HG. Acute health problems related to the operation mounted to clean the Hebei Spirit oil spill in Taean, Korea. Mar Pollut Bull 2010; 60: 51-57. https://doi.org/10.1016/j.marpolbul.2009.09.003.

[8] Andrea MAD, Reddy GK. Crude Oil Spill Exposure and Human Health Risks. JOEM 2014; 56: 1029-1041. https://doi.org/10.1097/JOM.0000000000000217.

[9] Adeothy-Koumakpaï S, Fayomi B, Lalya F, Sagbo GG, D'Almeida M, Anjorin A. Impact de la vente libre du carburant sur la santé des enfants au Bénin. Rev Du CAMES 2006; 04: 59-61.

[10] Alaba OC. Risk analysis in distribution of petroleum products in southwest, Nigeria. J Fundam Appl Sci 2018; 10: 370-382.

[11] Mama D, Dimon B, Aina M, Adounkpe J, Ahomadegbe M, Youssao A, et al. Transport urbain au Benin et pollution atmosphérique: évaluation quantitative de certains polluants chimiques de Cotonou. Int J Biol Chem Sci 2013; 7: 377-386. https://doi.org/10.4314/ijbcs.v7ili.33.

[12] Srivastava A, Barkule S. Airway function and mental health status of petrol pump workers of Aurangabad (Maharashtra) city. - An analytical cross-sectional study. Clin Epidemiol Glob Heal 2020; 8: 661-665. https://doi.org/10.1016/j.cegh.2019.12.022.

[13] Cairney S, Dingwall K. The mysterious practice of petrol sniffing in isolated indigenous groups. J Paediatr Child Health 2010; 46: 510-515.

[14] Solano-Serena F, Marchal R, Vandecasteele JP. Biodégradabilité de l'essence dans l'environnement : de l'évaluation globale au cas des hydrocarbures récalcitrants. Oil Gas Sci Technol 2001; 56: 479-498.

[15] Uzochukwu OC, Lilian OO, Uchenna OT, Ugbomhe UO. Business development and sustainability of selected petrol stations in Anambra state of Nigeria. African J Bus Manag 2018; 12: 11-20. https://doi.org/10.5897/AJBM2017.8456.

[16] Adesina EA, Odumosu JO, Morenikeji OO, Umoru E, Ayokanmbi AO, Ogunbode EB. Optimization of Fire Stations Services in Minna Metropolis using Maximum Covering Location Model (MCLM). J Appl Sci Environ Sustain 2017; 3: 172-187.

[17] INSAE. Que retenir des effectifs de population en 2013 ? Cotonou: 2013.

[18] Husson F, Lê S, Pagès J. Analyse de données avec R. 2e Edition. 2016. https://doi.org/10.4013/rechtd.2009.12.05.

[19] Cornillon P-A, Guyader A, Husson F, Jégou N, Josse J, Klutchnikoff $\mathrm{N}$, et al. $\mathrm{R}$ pour la statistique et la science des données. Saic. Rennes: 2018.

[20] Kiki VJM, Medenon A, Sèdjro R, Dossou-Cadja C. Modélisation du comportement du consommateur d'essence au Bénin. Rev d'Analyse Des Polit Econ Financ 2016; 2: 3-25.

[21] Eloundou MP. La vente illégale des hydrocarbures: conservation et problèmes de santé publique dans la ville de Maroua. Int J Res Eng Sci 2016; 4: 60-66.

[22] Adeyemi OJ, Ajibola A. Naira devaluation and trade balance in Nigeria. World Sci News 2019; 125: 181-192.

[23] Ogundipe OM, Ojeaga P, Ogundipe AA. Oil Price and Exchange Rate Volatility in Nigeria. J Econ Financ 2014; 5: 1-9. https://doi.org/10.9790/5933-0540109.

[24] Abdel Maksoud HA, Elharrif MG, Mahfouz MK, Omnia MA, Abdullah MH, Eltabey ME. Biochemical study on occupational inhalation of benzene vapours in petrol station. Respir Med Case Reports 2019; 27: 100836. https://doi.org/10.1016/j.rmcr.2019.100836.

[25] Uzma N, Kumar BS, Abdul M, Hazari H. Exposure to Benzene Induces Oxidative Stress, Alters the Immune Response and Expression of p53 in Gasoline Filling Workers. Am J Ind Med 2010; 53: 1264-1270. https://doi.org/10.1002/ajim.20901.

[26] Brosselin P, Rudant J, Orsi L, Leverger G, Baruchel A, Bertrand $\mathrm{Y}$, et al. Acute childhood leukaemia and residence next to petrol stations and automotive repair garages: the ESCALE study (SFCE). Occup Environ Med 2009; 66: 598606.

[27] Weng H-H, Tsai S-S, Chiu H-F, Wu T-N, Yang C-Y. Childhood Leukemia and Traffic Air Pollution in Taiwan: Petrol Station Density as an Indicator. J Toxicol Environ Heal Part A 2008; 83-87. https://doi.org/10.1080/15287390802477338. 
[28] Goussanou A, Youssao Abdoul Karim; Alassane, Toléba Séibou S, Dagan SB, Bonou AG, Chikou A, et al. Evaluation of crab Callinectes amnicola contamination by heavy metals $(\mathrm{Pb}, \mathrm{Cd}, \mathrm{Cu}, \mathrm{Zn}, \mathrm{Fe}, \mathrm{Cr}, \mathrm{Ni}, \mathrm{As})$ in the complex Nokoué lake Porto-novo lagoon in South Benin. Int J Biosci 2018; 12: 98110.

[29] Youssao A, Soclo HH, Bonou C, Vianou K, Gbaguidi M, Dovonon L. Evaluation de la contamination de la faune ichthyenne dans le complexe lagunaire Nokoué - chenal de Cotonou par le plomb : cas des espèces Sarotherodon melanotheron, Tilapia guineensis et Hemichromis fasciatus (Bénin). Int J Biol Chem Sci 2011; 5: 595-602.

[30] Youssao A, Soclo HH, Bonou C, Fayom B. Evaluation de la bioaccumulation du plomb dans les espèces animales marines et identification des sources de contamination métallique par une analyse multiélémentaire en métaux $(\mathrm{Al}, \mathrm{Cd}, \mathrm{Cr}, \mathrm{Cu}, \mathrm{Pb})$ dans les eaux côtières du Bénin. Int J Biol Chem Sci 2011; 5: $188-195$.

[31] Rashid A, Tao S, Uddin I, Kamal A. Petrol filling workers as biomonitor of PAH exposure and functional health capacity in resource-limited settings of city Rawalpindi, Pakistan. Environ Sci Pollut Res 2017; 24: 17881-17887. https://doi.org/10.1007/s11356-017-9372-z.

[32] Syimir Fizal AN, Sohrab Hossain M, Alkarkhi AFM, Oyekanmi AA, Hashim SRM, Khalil NA, et al. Assessment of the chemical hazard awareness of petrol tanker driver: A case study. Heliyon 2019; https://doi.org/10.1016/j.heliyon.2019.e02368.
[33] Moolla R, Curtis CJ, Knight J. Occupational exposure of diesel station workers to BTEX compounds at a bus depot. Int J Environ Res Public Health 2015; 12: 4101-4115. https://doi.org/10.3390/ijerph120404101.

[34] Naidoo RN, Makwela MH, Chuturgoon A, Tiloke C, Ramkaran P, Phulukdaree A. Petrol exposure and DNA integrity of peripheral lymphocytes. Int Arch Occup Environ Health 2016; 89: 785-792. https://doi.org/10.1007/s00420016-1116-8.

[35] Shaikh A, Barot D, Chandel D. Genotoxic Effects of Exposure to Gasoline Fumeson Petrol Pump Workers. Int J Occup Environ Med 2018; 9: 79-87.

[36] Durga M, Nathiya S, Rajasekar A, Devasena T. Effects of ultrafine petrol exhaust particles on cytotoxicity, oxidative stress generation, DNA damage and inflammation in human A549 lung cells and murine RAW 264.7 macrophages. Environ Toxicol Pharmacol 2014; 38: 518-530. https://doi.org/10.1016/j.etap.2014.08.003.

[37] Wu D, Zhang F, Lou W, Li D, Chen J. Chemical characterization and toxicity assessment of fine particulate matters emitted from the combustion of petrol and diesel fuels. Sci Total Environ 2017; 605: 172-179.

[38] Bindhya S, Balachandar V, Sudha S, Mohana Devi S, Varsha $\mathrm{P}$, Kandasamy $\mathrm{K}$, et al. Assessment of Occupational Cytogenetic Risk, Among Petrol Station Workers. Bull Environ Contam Toxicol 2010; 85: 121-124. https://doi.org/10.1007/s00128-010-0068-z. 